\title{
Violence and sexually transmitted infections in pregnancy
}

\author{
DSérgio Araujo Martins Teixeira,2 \\ (iD Stella R. Taquette \\ Denise Leite Maia Monteiro ${ }^{1,3}$
}

\begin{abstract}
1. Department of Post-Graduation in Medical Sciences, University of the State of Rio de Janeiro, Rio de Janeiro, Brasil 2. Institute of Education and Research Teixeira Ramos, Rio de Janeiro, Rio de Janeiro, Brasil 3. Department of Obstetrics and Gynecology - University Center Serra dos Órgãos, Teresópolis, Rio de Janeiro, Brasil
\end{abstract}

http://dx.doi.org/10.1590/1806-9282.65.3.475

\begin{abstract}
SUMMARY
OBJECTIVE: To synthesize the knowledge produced in studies about the association between violence and STI during pregnancy.

METHODS: In this systematic review, we conducted basic activities of identification, compilation, and registration of the trials. The instruments of data collection were studies that investigated, explicitly, relationships between violence, gestation, and STI, from July 2012 to July 2017, using PubMed, Cochrane Library, SciELO, and LILACS.

RESULTS: In all, 26 articles were chosen to form the basis of the analysis of this study. The relationship between violence and STI was observed in 22 of the 26 studies, and in eight of them, the violence was practiced during the gestation period. In two studies, there was no evidence of this relationship. In one study, the lack of care for STI was attributed to the unpreparedness of health professionals. Mental disorders were cited as resulting from STI in three articles and in another as a result of violence. One study found more frequent violence against adolescents, while two others cited gestation as a protective factor.

CONCLUSIONS: IPV combines characteristics that have a different expression when the woman is in the gestational period. The literature points to a relationship between IPV against women and the presence of STI. The monitoring of pregnancy, whether in the prenatal or postpartum period, offers unique opportunities for the health professional to identify situations of violence and thus provide assistance. KEYWORDS: Violence Against Women; Sexually Transmitted Infections; Pregnancy; Abortion; Stillbirth; Sex Offenses.
\end{abstract}

\section{INTRODUCTION}

Studies have pointed to a relationship between intimate partner violence (IPV) and sexually transmitted infection (STI) in women ${ }^{1,2}$, which makes it essential to detect this as part of the integrated healthcare, especially in the pregnancy-puerperal period, to protect the mother-child binomial. Identifying the presence of these diseases in the gestational period through clinical and serological diagnoses and correlating such findings with epidemiological data is fundamental so that, from this knowledge in our environment, we can establish early and timely preventive and/or therapeutic strategies or behaviors to avoid these infections which can lead to vertical transmission (VT).

The literature indicates not only the high prevalence of violence, as well as overlaps of several of its types in the gestational period ${ }^{3}$. Among them, there is sexual, psychological, and physical violence. Conjugal violence, practiced by an intimate partner, can combine characteristics of any of the above. Usually, it is used as a resource for interpersonal disputes, often complex, ambiguous, and with strong affective influence, in which local solutions go hand in hand with impunity ${ }^{4}$. 
The preparation of professionals to deal with cases of violence against women presents gaps in the supply of these demands ${ }^{5}$, and this contributes to the fact that the real magnitude of this social malaise remains unknown due to the high rate of underreporting $^{6}$. However, in the course of prenatal care, delivery, and puerperium, there is a great opportunity to identify situations of violence and propose protective actions ${ }^{7}$. Therefore, studies that go deeper into the subject and bring information about violence, in its various forms, can contribute to training programs, not only to physicians but to all health professionals who work in the pregnant-puerperal period. During the months of follow-up, a trained professional will have the chance to establish an important bond of trust, which will help in the diagnosis of violent situations and open the way to act in the most appropriate form.

The high prevalence of congenital syphilis points to deficiencies in basic healthcare, especially prenatal care since the diagnostic test is part of those recommended by the Ministry of Health. Its prevention depends on measures that eliminate or reduce the risk of fetal infection, such as early diagnosis and appropriate treatment of the pregnant woman and her partner ${ }^{8}$.

Also very prevalent, the Human papillomavirus (HPV), currently the most responsible for cervical cancer, appears as the most frequent viral STI. In a study of female adolescents between 10 and 14 years old, all of them sexually active, of the $22 \%$ who had some STI, $45 \%$ were caused by HPV ${ }^{9}$

HTLV infections are associated with several diseases such as adult T-cell leukemia/lymphoma (ATLL), myelopathy, tropical spastic paraparesis, uveitis, infectious dermatitis, rheumatic diseases, hairy cell leukemia, erythrodermatitis, bacterial infections coinfected with HIV, neurological diseases, and mycosis fungoides ${ }^{10,11}$. Transmission occurs through sexual intercourse, blood transfusions, injecting drugs, transplants, percutaneous exposure in health professionals, and through VT, especially through breastfeeding. The knowledge of the prevalence of infection in pregnant women and the factors related to a greater risk of VT in our country are of fundamental importance for prevention since there is no treatment and its consequences can be severe. There is no active or passive immunization, as well as specific antiviral therapy available against HTLV.

Therefore, the study of associations of situations of violence with STI in gestation provides subsidies for adopting preventive and protective measures, both for pregnant women and their newborns.

\section{OBJECTIVE}

To synthesize the knowledge produced by empirical studies in the health area on the association between violence and STI in gestation and subsidize new research and programs of prevention of IPV and vertical transmission of STI during pregnancy.

\section{METHODS}

In this systematic review, we chose four large databases namely: PubMed, SciELO, Cochrane, and LILACS.

We defined as inclusion criteria: articles that studied violence against pregnant women; articles that included the presence of STI during pregnancy; published in the last 5 years.

The search strategy used in PubMed, on 2018/01/12, was: (“"Violence” [Mesh]) AND "Pregnancy" [Mesh]) AND "Sexually Transmitted Diseases" [Mesh] Filters: 5 years. The following databases were searched: SciELO, Cochrane, and LILACS. In the SciELO, the descriptors Violence [All indexes] and Pregnancy [All indexes] and Sexually Transmitted Diseases [All indexes] were used. In Cochrane, it was used as search criteria: Violence and Pregnancy and Sexually Transmitted Diseases, Publication Year from 2012 to 2017. In LILACS we used the descriptors Violence [Words] and Pregnancy [Words] and Sexually Transmitted Diseases [Words].

\section{RESULTS}

Sixty-two studies were found in PubMed. In SciELO, no published works on these subjects were detected. In the LILACS database, of the four studies found, one was discarded by duplicity. Finally, in the Cochrane database, the survey found 28 bibliographic productions.

Ninety-three articles were selected in the screening of titles and abstracts, but six were excluded because they were protocols and consensuses.

After careful analysis of the 87 full texts, 10 were dismissed because they were literature reviews, 19 because they studied only one of the three themes chosen, and 32 because they focused on subjects that 
were not related with the objectives present here.

Thus, 26 articles were chosen to form the basis for the analysis of this study, according to the schematic flowchart described in Figure 1 of Annex I.

The relationship between violence and STIs was observed in 22 of the 26 pieces of research, and in eight of them, violence was practiced during gestation. In two trials, there was no evidence of this relationship. In one study, the lack of care for STI was attributed to the unpreparedness of health professionals. Mental disorders were cited as resulting from STI in three articles and in another as a result of violence. One study found more frequent violence against adolescents, while two others cited gestation as a protective factor.

The description of the design of each study, its authors, sample, objective, and results are detailed in Annex II. Another 21 articles were added to enrich the introduction and discussion. With this, the article used 47 bibliographical references.

\section{DISCUSSION}

Violence in pregnancy may can the most varied responses. IPV, in addition to having physical consequences, indirectly worsens maternal health because pregnant women, in fear of violent reprisals from partners, may avoid prenatal care. Some even hide HIV prenatal testing from their partners because it can be perceived as a sign of infidelity. Equally regrettable is how some communities banalize IPV as a common and intractable issue ${ }^{12 .}$ Some people voluntarily abandon marital life as a strategy to escape violence. Others are expelled from their homes when they dare to exercise their autonomy, possibly due to their HIV status ${ }^{13}$. In some places, IPV during pregnancy can reach alarming levels, as in research conducted in Zimbabwe where the reports reached $63.1 \%$ of the interviewed, which is among the highest rates in the world ${ }^{14}$. Other factors may arise in this context, as in the interventional research of Rotheram-Borus et al., where they found that, over time, there is a significant relationship between alcohol, marital violence, and depression. However, simple measures such as home visits demonstrated efficacy in improving the mothers' emotional health, even when depression was not initially the objective ${ }^{15}$. Even so, Jahanfar et al. failed to establish the efficacy of interventions for domestic violence on outcomes of maternal and neonatal morbidity and mortality ${ }^{16}$, although McDougal et al. have associated a history of miscarriage or stillbirth, not to physical violence but to sexual violence ${ }^{17}$. Therefore, high-quality work needs to be expanded to determine if intervention programs can prevent or reduce the deleterious effects of domestic violence on pregnant women and in pregnancy outcomes ${ }^{16}$.

Although violent situations are present in all age groups, the greatest vulnerability among adolescents must be observed. In research about the factors that influenced reproductive and sexual health among women entering the adolescent sex industry, four themes were highlighted: early sexual abuse, early use of illicit drugs, continuous violence, and difficulties in accessing reproductive and sexual healthcare $^{18}$. Recto and Champion highlighted the high risk of psychological distress in these adolescents involved in risk behaviors, victims of interpersonal violence, using illicit substances, or pregnant ${ }^{19}$. In a higher education institution in Colombia, students with a mean age of 20 years answered a self-administered questionnaire based on the Reproductive Health survey of the Pan American Health Organization. It was observed that had a history of pregnancy $(12.3 \%)$, physical violence $(21.6 \%)$, and sexual violence $(4.6 \%)$, with a predominant silence of victims of sexual abuse $(61.8 \%)^{20}$. Still among students, now in a high school located in a high-poverty region, about $20 \%$ of the girls surveyed between the ages of 14 and 17 reported a higher number of reproductive coercion than consensual intercourse. The most frequent reports were: "they said they did not use birth control," "took the condom out during sex to get pregnant," and "they said they would leave them if they were not pregnant." These adolescents had almost three times more chance to get chlamydia infection, had greater difficulty in recognizing abusive behavior and had worse communication with their sexual partners ${ }^{21}$.

The association between violence, mainly sexual, unwanted pregnancy, and STI after forced and unprotected sex is well known ${ }^{22}$. However, the low representation of female adolescents in HIV/AIDS clinical trials may inhibit their access to future prevention techniques. In a formative in a community in Tanzania, situations of violence and recruitment difficulties for HIV testing among adolescents and young women were studied. Domestic violence related to the partner was present in the report of all 


\section{ANNEX I}

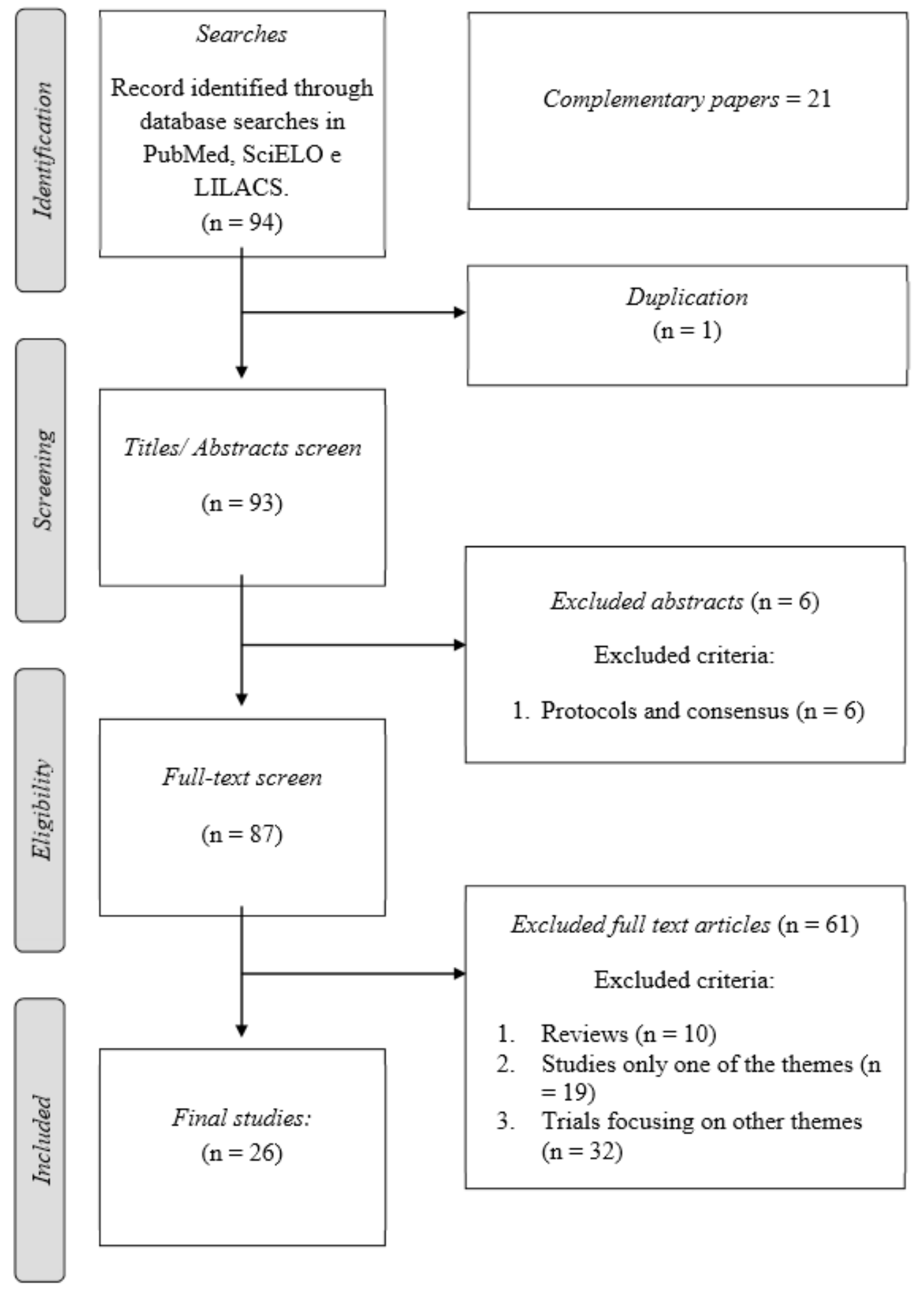


married participants. Many believed that beatings were normal. A third of the single women reported sexual abuse by relatives. Adolescents were the most frequent victims of domestic violence, often perpetrated by partners and relatives. It is, therefore, a public health priority to include adolescent abuse in HIV prevention ${ }^{23}$.

Sexual violence can also be associated with humiliation, torture, and beatings during violation; and rape can be practiced by several men. Although Perry et al. have not established a relationship between chlamydia, gonorrhea, and miscarriage after rape ${ }^{24}$, other studies point to the high prevalence and incidence of STI in women who suffer sexual crimes. They can often cause physical trauma, sexual disorders, unwanted pregnancy, psychological consequences, and even death. Thus, many of these women experience great uncertainty about their future and their children ${ }^{25,26 .}$

Already described in the literature, the relationships established between alcohol consumption and unprotected sexual intercourses indicate the incidence of HIV-positive women ${ }^{27}$. Some groups of pregnant women have the perception that IPV, an alcoholic partner, and lack of communication with the partner are forms of vulnerability that put them at risk of $\mathrm{HIV}^{28}$. A study conducted in Mombasa ${ }^{27}$ with 400 HIV-negative women showed associations between alcohol-abuse disorders, the incidence of one year of unprotected sexual intercourse, HIV, and pregnancy. Abusive alcohol users had more unprotected sex and more partners than abstainers. Sexual intercourse under the influence of alcohol was frequent and associated with less frequent use of a condom. Compared to women who were sober, those who consumed excess alcohol experienced 4.1 times more sexual violence and 8.4 times more risk to have physical violence. It is, thus, perceived that unprotected sex, partner violence, and HIV incidence were higher in women with alcohol abuse disorders, a fact corroborated by Russell et al. ${ }^{29}$.

In a study conducted in a hospital in Nigeria ${ }^{30}$, the prevalence and patterns of intimate partner violence among HIV-positive and HIV-negative pregnant women receiving prenatal care were compared. In a total of 220 pregnant women, it was found that the cases did not differ significantly from the controls in relation to age, parity, tribe, religion, marital status, and monthly family income. Those interviewed with HIV positive experienced physi- cal violence during pregnancy with rates six times higher than in controls, sexual violence about four times higher than in controls, and were 12 times more likely to be denied sex by their partner in comparison with the controls. The threat of being harmed, deprivation of financial support, and denial of communication were the most common forms of violence between sexual partners and HIV-positive pregnant women. In this study, HIV-positive status predisposes pregnant women to the increase in intimate partner violence but underlies the great impact of social rejection suffered as a result of HIV infection. It is worth remembering that, in addition to physical and psychological trauma in women, IPV also increases the chance of vertical transmission 31. In another region of Africa, Charlotte Watts and Janet Seeley ${ }^{32}$ address gender inequality and intimate partner violence as obstacles to a confrontation with an effective response to HIV. In this place, women and girls represent $57 \%$ of people living with HIV, and gender violence and inequality are determinants of vulnerability. Research shows qualitative data from women attending prenatal clinics in Johannesburg, which shows how the diagnosis of HIV during pregnancy and disclosure to the partner are relevant aspects of the occurrence of violence in the relationship. Low adherence to medications and the use of relief services are also described. Likewise, how the use of these services may be difficult since women feared that their partners would be alerted about their HIV status. Pregnant women also described that they could not refuse sex or negotiate condom use, prioritizing the physical safety of an unborn baby during pregnancy to the detriment of potential secondary transmission of HIV. Still in Africa, even in the absence of violence, several risk behaviors are pointed out during pregnancy, resulting from local customs and lack of information, such as the belief that antiretroviral drugs can cure HIV ${ }^{33,34}$. It is worth noting the efforts in South Africa in the fight against HIV, prevention of injuries and violence, in addition to initiatives for the promotion of maternal, neonatal, and child health ${ }^{35}$. Thus, there is still a long way to go.

National HIV prevention programs in Mexico focus on high-risk groups that do not include women in general. Although the epidemic is growing among them, their testing is restricted to prenatal screening. Even so, in a survey conducted in Mexico City, only $6 \%$ of the controls were tested for HIV 


\section{ANNEX II}

TABLE 1 DETAILED DESCRIPTION OF THE ARTICLES USED IN THIS REVIEW.

\begin{tabular}{|c|c|c|c|c|}
\hline Autor/ Year & Design & Sample & Objective & Results \\
\hline Oza et al., 2015 & cohort & $25 q$ & $\begin{array}{l}\text { Explore experiences during childhood } \\
\text { and adolescence that influenced the } \\
\text { sexual and reproductive health among } \\
\text { women who entered in the sex industry. }\end{array}$ & $\begin{array}{l}\text { Identified four main themes: early sexual abuse, early } \\
\text { use of illicit drugs, ongoing violence and limited access } \\
\text { to health care. The participants who reported these } \\
\text { experiences face the risk of unintended pregnancy, } \\
\text { miscarriage or stillbirth, and untreated STIs.ace }\end{array}$ \\
\hline Recto \& Champion, 2016 & transversal & $461+9$ & $\begin{array}{l}\text { To study psychological disturbance and } \\
\text { associated factors among adolescents. }\end{array}$ & $\begin{array}{l}\text { Adolescents in risk behaviors, interpersonal violence, } \\
\text { use of illicit substances and pregnant women are at risk } \\
\text { of psychological distress. }\end{array}$ \\
\hline $\begin{array}{l}\text { Gómez-Camargo et al., } \\
2014\end{array}$ & transversal & 934 우 & $\begin{array}{l}\text { To investigate the state of sexual and } \\
\text { reproductive health among university } \\
\text { students in Colombia. }\end{array}$ & $\begin{array}{l}\text { 12.3\% had a history of pregnancy; physical violence } \\
(21.6 \%) \text {, sexual violence }(4.6 \% \text {, predominant silence of } \\
\text { victims of sexual abuse }(61.8 \%) \text {, history of STI }(1.9 \%) \\
\text { and history of symptoms suggestive of STI }(42 \%) \text {. }\end{array}$ \\
\hline Northridge et al., 2017 & transversal & $149+$ & $\begin{array}{l}\text { To determine the prevalence of repro- } \\
\text { ductive coercion and IPV, and risks to } \\
\text { health. }\end{array}$ & $\begin{array}{l}\text { Reproductive coercion is experienced by } 1 \text { in } 5 \text { girls of } \\
\text { school age in a poor community and is associated with } \\
\text { chlamydia and IPV infection. }\end{array}$ \\
\hline Baumgartner et al., 2015 & $\begin{array}{l}\text { Clinical } \\
\text { trial }\end{array}$ & 138 ㅇ & $\begin{array}{l}\text { Measure IPV and examine the associa- } \\
\text { tions between risk factors, sociodemo- } \\
\text { graphic factors, and HIV risk factors. }\end{array}$ & $\begin{array}{l}\text { Married women reported IPV. Many believed that } \\
\text { beatings were normal. One-third of the single women } \\
\text { reported abuse by relatives. Teenagers have experienced } \\
\text { high rates of domestic violence, and young people were } \\
\text { more likely to report aggression. }\end{array}$ \\
\hline Secor-Turner et al., 2013 & cohort & $241+9$ & $\begin{array}{l}\text { Understand the interaction of multiple } \\
\text { contexts of sexual risk behaviors of } \\
\text { adolescents. }\end{array}$ & $\begin{array}{l}\text { The latent construction of individual risk encompasses } \\
\text { the use of illicit substances, the perpetration of violence, } \\
\text { having suffered violence and witnessing situations } \\
\text { of violence; the family breakdown included family } \\
\text { disconnection, low-income family communication and } \\
\text { perception of lack of safety at home. }\end{array}$ \\
\hline Perry et al., 2015 & transversal & $\begin{array}{l}19465 \text { preg- } \\
\text { nant women }\end{array}$ & $\begin{array}{l}\text { To estimate the prevalence of rape-re- } \\
\text { lated pregnancy as an indication for } \\
\text { abortion and to describe the demo- } \\
\text { graphic and clinical correlations of these } \\
\text { women. }\end{array}$ & $\begin{array}{l}\text { Chlamydia and gonorrhea infection were no more } \\
\text { prevalent among women who completed rape-related } \\
\text { pregnancies than among those who ended up with } \\
\text { other indications. }\end{array}$ \\
\hline $\begin{array}{l}\text { Zihindula \& Maharaj, } \\
2015\end{array}$ & cohort & $19 q$ & $\begin{array}{l}\text { Explore the perceptions and experienc- } \\
\text { es of the risk of sexual violence in the } \\
\text { Democratic Republic of Congo. }\end{array}$ & $\begin{array}{l}\text { Rape used to have extreme brutality against women, } \\
\text { with long-term consequences, including unwanted } \\
\text { pregnancies and/or HIV/AIDS. Many have lived with } \\
\text { uncertainty about their future and that of their children. }\end{array}$ \\
\hline Ceccon \& Meneghel, 2015 & transversal & $161+\mathrm{HIV}+$ & $\begin{array}{l}\text { To determine the prevalence and forms } \\
\text { of violence. }\end{array}$ & $\begin{array}{l}\text { Psychological violence (72.7\%), physical (54.6\%) and } \\
\text { sexual violence (25.4\%). }\end{array}$ \\
\hline Turan et al.,2016 & cohort & $\begin{array}{l}614 \text { preg- } \\
\text { nant women }\end{array}$ & $\begin{array}{l}\text { Explore the forced migration of pregnant } \\
\text { women in an area of high HIV prev- } \\
\text { alence as a strategy to escape from a } \\
\text { violent partner. }\end{array}$ & $\begin{array}{l}\text { Violent situations in pregnancy, such as voluntary leav- } \\
\text { ing home to escape violence or being kicked out for ex- } \\
\text { ercising autonomy. In the quantitative analysis, pregnant } \\
\text { women who migrated were more educated, less likely to } \\
\text { live with their partners and with fewer children. }\end{array}$ \\
\hline Shamu et al., 2013 & transversal & $\begin{array}{l}2042 \\
\text { puerperal } \\
\text { women }\end{array}$ & $\begin{array}{l}\text { To describe the occurrence, dynamics, } \\
\text { and predictors of IPV during pregnancy, } \\
\text { including HIV links, in urban Zimbabwe. }\end{array}$ & $\begin{array}{l}63.1 \% \text { of the interviewees reported physical, emotional } \\
\text { and/or sexual IPV during pregnancy: } 46.2 \% \text { reported } \\
\text { physical and/or sexual violence, } 38.9 \% \text { sexual violence, } \\
15.9 \% \text { physical violence and } 10 \% \text { reported severe } \\
\text { violence during pregnancy. Physical violence was less } \\
\text { common during pregnancy than in the last } 12 \text { months } \\
\text { before pregnancy. }\end{array}$ \\
\hline Hatcher et al., 2013 & transversal & $\begin{array}{l}29 \text { pregnant } \\
\text { women }\end{array}$ & $\begin{array}{l}\text { Explore the context and triggers of IPV } \\
\text { in general and for pregnant women in } \\
\text { rural Kenya. }\end{array}$ & $\begin{array}{l}\text { Physical consequences and IPV induce pregnant women } \\
\text { to avoid prenatal care and HIV testing because they fear } \\
\text { violent reprisals from partners. The }+ \text { suffered physical, } \\
\text { sexual and economic IPV, such as being kicked out of } \\
\text { home or losing material support. They hide the HIV test } \\
\text { from their partners because the test is seen as a sign of } \\
\text { infidelity. The community considers IPV a common and } \\
\text { untreatable issue, which seemed to normalize its use. }\end{array}$ \\
\hline Teixeira et al., 2017 & transversal & $681 ㅇ$ & $\begin{array}{l}\text { To analyze the factors associated with } \\
\text { the occurrence of pregnancy after the } \\
\text { diagnosis of HIV infection. }\end{array}$ & $\begin{array}{l}\text { Violence related to the diagnosis of HIV/AIDS. Pregnan- } \\
\text { cy after a diagnosis of HIV infection }=35.2 \% \text {. Pregnancy } \\
\text { after an HIV diagnosis is associated with a lower level of } \\
\text { schooling. }\end{array}$ \\
\hline Aguilar-Zapata et al., 2017 & $\begin{array}{l}\text { case-con- } \\
\text { trol }\end{array}$ & $\begin{array}{l}152 \text { preg- } \\
\text { nant women }\end{array}$ & $\begin{array}{l}\text { To study sociodemographic differences } \\
\text { between recent pregnant women HIV } \\
\text { positive and HIV negative. }\end{array}$ & $\begin{array}{l}\text { Strong evidence of an association between HIV infec- } \\
\text { tion, STI history and history of violence. Only } 6 \% \text { of } \\
\text { controls were tested for HIV during prenatal follow-up. }\end{array}$ \\
\hline
\end{tabular}




\begin{tabular}{|c|c|c|c|c|}
\hline Autor/ Year & Design & Sample & Objective & Results \\
\hline McDougal et al., 2013 & cohort & 582 우 & $\begin{array}{l}\text { To examine the prevalence of gestation- } \\
\text { al losses among female professionals } \\
\text { who inject drugs and measure their } \\
\text { associations with physical and sexual } \\
\text { violence. }\end{array}$ & $\begin{array}{l}30 \% \text { of participants had at least one miscarriage/ } \\
\text { stillbirth, } 51 \% \text { suffered sexual violence, and } 49 \% \text { had } \\
\text { suffered physical violence. The history of miscarriage/ } \\
\text { stillbirth was associated with sexual violence, but not } \\
\text { with physical violence. }\end{array}$ \\
\hline Narasimhan et al.,2016 & transversal & $\begin{array}{l}945 \text { o HIV- } \\
\text { positive }\end{array}$ & $\begin{array}{l}\text { Determine the sexual and reproductive } \\
\text { health priorities of women with HIV and } \\
\text { apply their values and preferences to the } \\
\text { construction of new guidelines. }\end{array}$ & $\begin{array}{l}89.0 \% \text { feared or suffered gender violence; } 56.7 \% \text { had } \\
\text { an unplanned pregnancy; } 72.3 \% \text { received advice on } \\
\text { contraception; } 58.8 \% \text { had mental problems after they } \\
\text { discovered their HIV status. }\end{array}$ \\
\hline Ashaba et al., 2017 & cohort & $20+$ & $\begin{array}{l}\text { Explore the psychosocial challenges } \\
\text { experienced by women living with HIV } \\
\text { during pregnancy and postpartum. }\end{array}$ & $\begin{array}{l}\text { Discrimination of health professionals and personal } \\
\text { shame associated with pregnancy with HIV has led to } \\
\text { the difficulty of care of HIV, especially when associated } \\
\text { with structural barriers such as the lack of transport to } \\
\text { the clinic. IPV and lack of support from partners and } \\
\text { family members. }\end{array}$ \\
\hline Maman et al.,2016 & transversal & 1092 웅 & $\begin{array}{l}\text { Examine whether HIV increases the } \\
\text { risk of IPV in the postpartum and the } \\
\text { interaction in its disclosure. }\end{array}$ & $\begin{array}{l}\text { HIV was not associated with physical IPV in the post- } \\
\text { partum period. Statistically significant positive interac- } \\
\text { tion between HIV and its disclosure. }\end{array}$ \\
\hline Shamu et al., 2014 & transversal & $\begin{array}{l}1951 \\
\text { puerperal } \\
\text { women }\end{array}$ & $\begin{array}{l}\text { Study the IPV after disclosure of HIV } \\
\text { test results by pregnant women. }\end{array}$ & $\begin{array}{l}\text { Factors associated with IPV were gender inequality, past } \\
\text { of IPV, risky sexual behaviors and living with relatives. } \\
\text { The IPV after the disclosure of HIV in pregnancy } \\
\text { although lower is still high and strongly related to IPV } \\
\text { before pregnancy. }\end{array}$ \\
\hline Malaju \& Alene, 2013 & transversal & $\begin{array}{l}400 \text { preg- } \\
\text { nant women }\end{array}$ & $\begin{array}{l}\text { To study the reaction of the partners } \\
\text { regarding the positive result for HIV in } \\
\text { pregnant women. }\end{array}$ & $\begin{array}{l}78.50 \% \text { expected a negative reaction from their partners } \\
\text { over the positive HIV test. A positive reaction was } \\
\text { associated to pregnant women with their own income, } \\
\text { residing in urban areas, with a higher educational level, } \\
\text { without a stigmatizing attitude with people living with } \\
\text { HIV and having access to health care facilities. }\end{array}$ \\
\hline Hampanda, 2016 & transversal & $\begin{array}{l}320 \text { \& HIV+ } \\
\text { in the post- } \\
\text { partum }\end{array}$ & $\begin{array}{l}\text { To determine if there is a relationship } \\
\text { between IPV and non-adherence to VT } \\
\text { prevention. }\end{array}$ & $\begin{array}{l}\text { Intimate partner violence is associated with non-adher- } \\
\text { ence to VT prevention during and after pregnancy. }\end{array}$ \\
\hline Peltzer et al., 2013 & cohort & $\begin{array}{l}239 \text { couples } \\
\text { with preg- } \\
\text { nant women } \\
\text { ( } \mathrm{n}=478 \\
\text { individuals) }\end{array}$ & $\begin{array}{l}\text { Describe the high-risk sexual behavior } \\
\text { among } 239 \text { couples during pregnancy, } \\
\text { examine the relationship of sexual risk } \\
\text { behavior to HIV serostatus and intimate } \\
\text { partner violence. }\end{array}$ & $\begin{array}{l}31.8 \% \text { of the pregnant women and } 20.9 \% \text { of the } \delta \\
\text { were HIV positive, with } \pm 2 / 3 \text { knowing their serological } \\
\text { status. } 46.9 \% \text { of the } q \text { did not know the HIV status of } \\
\text { their partner. } 47.7 \% \text { o reported at least one unprotect- } \\
\text { ed sexual relation in the previous week. } 17.6 \% \text { of the } \\
\hat{0} \text { and } 10.0 \% \text { of the } q \text { indicated sexual intercourses } \\
\text { with another person in the previous month. IPVs were } \\
\text { associated with unprotected intercourse in the previous } \\
\text { week. }\end{array}$ \\
\hline Peltzer \& Mlambo, 2013 & transversal & $\begin{array}{l}1502 \text { preg- } \\
\text { nant }\end{array}$ & $\begin{array}{l}\text { To assess the sexual behavior of HIV } \\
\text { risk and its associated factors among } \\
\text { pregnant women in Mpumalanga, South } \\
\text { Africa. }\end{array}$ & $\begin{array}{l}63 \% \text { never used a condom with their primary sexual } \\
\text { partner in the last } 3 \text { months, } 60 \% \text { did not know the } \\
\text { partner's HIV status. Behaviors found: being HIV pos- } \\
\text { itive, experiencing partner violence and psychological } \\
\text { distress due to the diagnosis of an STI other than HIV, } \\
\text { unplanned pregnancy, belief that the medications cure } \\
\text { HIV. }\end{array}$ \\
\hline Chersich et al., 2014 & cohort & 400 운 & $\begin{array}{l}\text { Investigate alleged links between alcohol } \\
\text { consumption, unprotected sex and HIV } \\
\text { infection in sub-Saharan Africa. }\end{array}$ & $\begin{array}{l}\text { Excessive alcohol led to more unprotected sex and } \\
\text { a higher number of partners. Sex, when the woman } \\
\text { was intoxicated, was frequent and associated with less } \\
\text { frequent condom use. The occurrence of accidents with } \\
\text { condoms has increased steadily with each increase in } \\
\text { the AUDIT category. Associated violence and HIV inci- } \\
\text { dence are higher in } q \text { with alcohol use disorders. }\end{array}$ \\
\hline Darak et al., 2014 & cohort & 460 운 & $\begin{array}{l}\text { Investigate women who, within the low- } \\
\text { risk population, are potentially at higher } \\
\text { risk of HIV infection. }\end{array}$ & $\begin{array}{l}\text { 19.4\% of women perceived themselves to be at risk of } \\
\text { HIV, and most of them reported some vulnerability } \\
\text { in their relationship as couples, such as IPV, alcoholic } \\
\text { partner and lack of communication with partners. }\end{array}$ \\
\hline $\begin{array}{l}\text { Rotheram-Borus et al., } \\
2015\end{array}$ & transversal & $\begin{array}{l}1238 \text { preg- } \\
\text { nant women }\end{array}$ & $\begin{array}{l}\text { To compare the standard care condition } \\
\text { with the condition of home intervention } \\
\text { in the use of alcohol, IPV and depres- } \\
\text { sion. }\end{array}$ & $\begin{array}{l}\text { Alcohol, conjugal violence, and depression are sig- } \\
\text { nificantly related over time. A home visit intervention } \\
\text { improved the emotional health of low-income mothers, } \\
\text { even when depression was not the initial target. }\end{array}$ \\
\hline 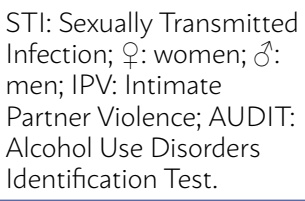 & & & & \\
\hline
\end{tabular}


during prenatal care, which indicates a great fragility of the system ${ }^{36}$.

In a survey with HIV-positive women, the majority (89.0\%) feared or suffered gender-based violence, with more than half having an unplanned pregnancy and $58.8 \%$ experiencing psychiatric problems after discovering they had HIV $^{37}$. Maman found a higher frequency of IPV among those who chose not to disclose to their partners their positive HIV status, perhaps because they had other problems in their relationships ${ }^{38}$. On the other hand, Shamu et al. found that IPV after disclosure of HIV positivity in pregnancy is also high, but lower and strongly related to IPV before pregnancy ${ }^{39}$. An exception was found by Malaju and Alene in an Ethiopian city called Gondar, they found positive reactions in partners who received results of an HIV positive test from their partners when they were financially independent and had good schooling ${ }^{40}$.

Violence against women also has a high occurrence in Brazil and, in general, is the result of unequal relationships where the man expresses his will with greater power. HIV infection is a major concern for most women in situations of sexual violence, a fact that is justified by its higher incidence, in addition to other types, in the seropositive group ${ }^{41,42}$. Research carried out in the South of Brazil on the occurrence of pregnancies after a diagnosis of HIV infection has shown that this fact indicates the lack of a guarantee of the reproductive rights of women living with HIV/ AIDS, since these pregnancies usually occur in contexts of great vulnerability ${ }^{43}$.

“Though preventable, globally, each year about two million pregnant women become infected with syphilis." This statement by Shahrook et al. in their study about screening strategies during prenatal care portrays the situation of this malady that has been sweeping the world for decades. In this research, the proactive strategy of local screening for syphilis in prenatal care demonstrated better results on adequate treatment, of both the partner and the mother, which reflected in a lower incidence of congenital syphilis ${ }^{44}$. Thus, the importance of basic care during the opportunity of prenatal care is emphasized to track, address, and manage problems related to violence and STIs. However, the identification of the of violence is not always welcomed by the victim or even by health professionals, who have demonstrated unpreparedness for these care ${ }^{45}$. In addition, according to Ashaba, women can feel a stigma caused by the discrimination of health professionals themselves and the personal shame associated with pregnancy as HIV-positive women. This can make it difficult to engage in HIV care, especially in the presence of structural barriers, such as the difficulty of transport to the clinic. Added to this, the participants in their study also experienced intimate partner violence and lack of support from their families ${ }^{46}$. Therefore, in order to better meet the health needs of pregnant women, health systems must incorporate coordinated and interdisciplinary services that perform contextual analysis, in which relevant family and social aspects of pregnant women are considered ${ }^{47}$.

\section{CONCLUSIONS}

Marital violence, perpetrated by an intimate partner, has characteristics that are perpetuating within the relationship, and manifest differently when the woman is in the gestational period. The replacement of physical violence by psychological is one of the ways to mask the harmful effects practiced by the partner since its identification is usually more difficult. These women may present, to a greater degree, symptoms of anxiety and post-traumatic stress.

Several studies show the high magnitude of violence practiced by partners, with severe and recurrent episodes. Cases of sexual violence, accompanied by physical aggression demonstrate the victim's difficulty in responding and leave them in a state of vulnerability.

The literature points to a relationship between intimate partner violence against women and the presence of sexually transmitted infections, which would make it essential to detection it as part of women's basic healthcare. HIV infection is a major concern for most women in situations of sexual violence. Studies have shown a higher prevalence of partner violence in HIV-positive pregnant women associated with unprotected sex and abusive use of alcohol.

Based on the results of the present study, we emphasize that violence against women is a significant public health problem. The follow-up periods in the gestational phase, whether in the prenatal or postpartum period, are unique opportunities for health professionals to identify situations of violence and thus provide assistance. 


\section{RESUMO}

OBJETIVO: Sintetizar o conhecimento produzido em estudos sobre a associação entre violência e IST na gestação.

MÉTODOS: Nesta revisão sistemática, envolvemos as atividades básicas de identificação, compilação e registro dos ensaios. Os instrumentos de coleta de dados foram os estudos que investigaram, explicitamente, as relações entre violência e gestação e IST, no período de julho de 2012 a julho de 2017, utilizando PubMed, Biblioteca Cochrane, SciELO e Lilacs.

RESULTADOS: Ao todo, 26 artigos foram escolhidos para formar a base da análise deste estudo. A relação entre violência e IST foi observada em 22 dos 26 estudos, sendo que em oito deles a violência foi praticada durante o período de gestação. Em dois estudos, não houve evidências dessa relação. Em um estudo, a falta de cuidados com a IST foi atribuída ao despreparo dos profissionais de saúde. Transtornos mentais foram citados como resultantes de IST em três artigos e em outro como resultado de violência. Um estudo encontrou violência mais frequente contra adolescentes, enquanto outros dois citaram a gestação como um fator de proteção.

CONCLUSÕES: A VPI combina características que possuem uma expressão diferenciada quando a mulher está no período gestacional. A literatura aponta para uma relação entre a VPI contra as mulheres e a presença de IST. O acompanhamento da gravidez, seja no pré-parto, seja no pós-parto, oferece oportunidades únicas para o profissional de saúde identificar situações de violência e, assim, prestar assistência.

PALAVRAS-CHAVE: Violência contra as mulheres. Infecções sexualmente transmissiveis. Gravidez. Aborto. Natimorto. Ofensas sexuais.

\section{REFERENCES}

1. Barros C, Schraiber LB, França-Junior I. Associação entre violência por parceiro íntimo contra a mulher e infecção por HIV. Rev Saude Publica [Internet]. 2011 Apr [cited 2012 Nov 7];45(2):365-72. Available from: http://www.scielo.br/scielo.php?script=sci_arttext\&pid=S0034-89102011000200015\&lng=pt\&nrm=iso\&tlng=en

2. Walsh LL, Senn TE, Carey MP. Exposure to different types of violence and subsequent sexual risk behavior among female sexually transmitted disease clinic patients: A latent class analysis. Psychol Violence [Internet]. 2012;2(4):339-54. Available from: http://doi.apa.org/getdoi.cfm?doi=10.1037/a0027716

3. Schraiber LB, D'Oliveira AFPL, França-Junior I, Diniz S, Portella AP, Ludermir $A B$, et al. Prevalência da violência contra a mulher por parceiro íntimo em regiões do Brasil. Rev Saude Publica [Internet]. 2007 Oct;41(5):797807. Available from: http://www.scielo.br/scielo.php?script=sci_arttext\&pid=S0034-89102007000500014\&lng=pt\&nrm=iso\&tlng=pt

4. Rifiotis T. As delegacias especiais de proteção à mulher no Brasil e a «judiciarização» dos conflitos conjugais. Soc e Estado. 2004;19(1):85-119.

5. Pedrosa CM, Spink MJP. A violência contra mulher no cotidiano dos serviços de saúde: desafios para a formação médica. Saúde e Soc [Internet]. 2011 Mar;20(1):124-35. Available from: http://www.scielo.br/scielo. php?script=sci_arttext\&pid=S0104-12902011000100015\&lng=pt\&n$\mathrm{rm}=\mathrm{iso} \& \mathrm{t} \operatorname{lng}=\mathrm{pt}$

6. Okabe I, Fonseca RMGS da. Violência contra a mulher: contribuições e limitações do sistema de informação. Rev da Esc Enferm da USP [Internet]. 2009 Jun;43(2):453-8. Available from: http://www.scielo.br/scielo. php?script=sci_arttext\&pid=S0080-62342009000200027\&lng=pt\&nrm=iso\&tlng=pt

7. Silva EP, Ludermir $A B$, Araújo TVB de, Valongueiro SA. Freqüência e padrão da violência por parceiro íntimo antes, durante e depois da gravidez. Rev Saude Publica [Internet]. 2011 Dec;45(6):1044-53. Available from: http://www.scielo.br/scielo.php?script=sci_arttext\&pid=S0034-89102011000600006\&lng=pt\&nrm=iso\&tlng=en

8. Domingues RMSM, Saracen V, Hartz ZM de A, Leal M do C. Sífilis congênita: evento sentinela da qualidade da assistência pré-natal. Rev Saude Publica [Internet]. 2013;47(1):147-57. Available from: http://www.scielosp. org/scielo.php?script=sci_arttext\&pid=S0034-89102013000100019

9. Teixeira SAM, Taquette SR. Violência e atividade sexual desprotegida em adolescentes menores de 15 anos. Rev Assoc Med Bras. 2010;56(4):4406.

10. Goncalves DU, Proietti FA, Ribas JGR, Araujo MG, Pinheiro SR, Guedes $A C$, et al. Epidemiology, Treatment, and Prevention of Human T-Cell Leukemia Virus Type 1-Associated Diseases. Clin Microbiol Rev [Internet]. 2010 Jul 1;23(3):577-89. Available from: http://cmr.asm.org/cgi/ doi/10.1128/CMR.00063-09

11. Bittencourt AL, Primo |, Oliveira M de FP de. Manifestations of the human T-cell lymphotropic virus type I infection in childhood and adolescence. J Pediatr (Rio J) [Internet]. 2006 Dec 13;82(6):411-20. Available from: http://www.jped.com.br/conteudo/Ing_resumo.asp?varArtigo $=1573 \& \operatorname{cod}=\& i d S e c a o=3$
12. Hatcher AM, Romito P, Odero M, Bukusi EA, Onono M, Turan JM. Social context and drivers of intimate partner violence in rural Kenya: implications for the health of pregnant women. Cult Health Sex [Internet]. 2013 Apr;15(4):404-19. Available from: http://www.tandfonline.com/doi/abs/1 0.1080/13691058.2012.760205

13. Turan $M$, Hatcher AM, Romito P, Mangone E, Durojaiye M, Odero M, et al. Intimate partner violence and forced migration during pregnancy: Structural constraints to women's agency. Glob Public Health [Internet]. 2016 Feb 7;11(1-2):153-68. Available from: http://dx.plos.org/10.1371/ journal.pone.0176256

14. Shamu S, Abrahams N, Zarowsky C, Shefer T, Temmerman M. Intimate partner violence during pregnancy in Zimbabwe: a cross-sectional study of prevalence, predictors and associations with HIV. Trop Med Int Heal [Internet]. 2013 Jun;18(6):696-711. Available from: http://doi.wiley. com/10.1111/tmi.12078

15. Rotheram-Borus MJ, Tomlinson M, Roux I Le, Stein JA. Alcohol Use, Partner Violence, and Depression. Am J Prev Med [Internet]. 2015 Nov;49(5):715-25. Available from: http://linkinghub.elsevier.com/retrieve/pii/S0749379715002251

16. Jahanfar S, Janssen PA, Howard LM, Dowswell T. Interventions for preventing or reducing domestic violence against pregnant women. Cochrane database Syst Rev [Internet]. 2013 Feb 28;(2):CD009414. Available from: http://www.ncbi.nlm.nih.gov/pubmed/23450603

17. McDougal L, Strathdee SA, Rangel G, Martinez G, Vera A, Sirotin N, et al. Adverse pregnancy outcomes and sexual violence among female sex workers who inject drugs on the United States-Mexico border. Violence Vict [Internet]. 2013 Jun;28(3):496-512. Available from: http://linkinghub. elsevier.com/retrieve/pii/S0048357511000411

18. Oza KK, Silverman JG, Bojorquez I, Strathdee SA, Goldenberg SM. Examining negative effects of early life experiences on reproductive and sexual health among female sex workers in Tijuana, Mexico. Int | Gynecol Obstet [Internet]. 2015 Feb;128(2):169-73. Available from: http://doi.wiley. com/10.1016/j.ijgo.2014.08.014

19. Recto P, Champion JD. Psychological Distress and Associated Factors Among Mexican American Adolescent Females. Hisp Heal Care Int [Internet]. 2016 Dec 16;14(4):170-6. Available from: http://journals.sagepub. com/doi/10.1177/1540415316676224

20. Gómez Camargo DE, Ochoa Diaz MM, Canchila Barrios CA, Ramos Clason EC, Salguedo Madrid Gl, Malambo García DI. Salud sexual y reproductiva en estudiantes universitarios de una institución de educación superior en Colombia. Rev Salud Pública [Internet]. 2015;16(5):660-72. Available from: http://www.revistas.unal.edu.co/index.php/revsaludpublica/article/view/39998

21. Northridge JL, Silver EJ, Talib HJ, Coupey SM. Reproductive Coercion in High School-Aged Girls: Associations with Reproductive Health Risk and Intimate Partner Violence. I Pediatr Adolesc Gynecol [Internet]. 2017;30(6):603-8. Available from: https://doi.org/10.1016/j. jpag.2017.06.007

22. Blake MDT, Drezett J, Machi GS, Pereira VX, Raimundo RD, Oliveira FR, 
et al. Factors associated to late-term abortion after rape: literature review. Reprodução Clim [Internet]. 2014 May;29(2):60-5. Available from: http:// dx.doi.org/10.1016/j.recli.2014.08.003

23. Baumgartner JN, Kaaya S, Karungula H, Kaale A, Headley |, Tolley E. Domestic violence among adolescents in HIV prevention research in Tanzania: participant experiences and measurement issues. Matern Child Health | [Internet]. 2015 Jan;19(1):33-9. Available from: http://link.springer.com/article/10.1007/s10995?014?1492?1

24. Perry R, Zimmerman L, Al-Saden I, Fatima A, Cowett A, Patel A. Prevalence of rape-related pregnancy as an indication for abortion at two urban family planning clinics. Contraception [Internet]. 2015:91(5):393-7. Available from: http://dx.doi.org/10.1016/j.contraception.2015.01.012

25. Drezett |, Blake MDT, Lira KSF de, Pimentel RM, Adami F, Bessa MMM, et al. Doenças sexualmente transmissíveis em mulheres que sofrem crimes sexuais. Reprodução Clim [Internet]. 2012 Sep;27(3):109-16. Available from: http://dx.doi.org/10.1016/j.recli.2013.03.004

26. Zihindula G, Maharaj P. Risk of sexual violence: Perspectives and experiences of women in a hospital in the Democratic Republic of Congo. Community Health [Internet]. 2015:40(4):736-43. Available from: http:// dx.doi.org/10.1007/s10900-015-9992-5

27. Chersich MF, Bosire W, King N, Temmerman M, Luchters S. Effects of hazardous and harmful alcohol use on HIV incidence and sexual behaviour: a cohort study of Kenyan female sex workers. Global Health [Internet]. 2014;10(1):1-11. Available from: Globalization and Health

28. Darak S, Gadgil M, Balestre E, Kulkarni M, Kulkarni V, Kulkarni S, et al. HIV risk perception among pregnant women in western India: Need for reducing vulnerabilities rather than improving knowledge! AIDS Care [Internet]. 2014 Jun 3;26(6):709-15. Available from: http://www.tandfonline. com/doi/abs/10.1080/09540121.2013.855303

29. Russell BS, Eaton LA, Petersen-Williams P. Intersecting epidemics among pregnant women: alcohol use, interpersonal violence, and HIV infection in South Africa. Curr HIV/AIDS Rep [Internet]. 2013 Mar 12;10(1):103-10. Available from: http://link.springer.com/10.1007/s11904-012-0145-5

30. Hyginus E, Chukwuemeka I, Lawrence I, Sunday M. HIV-related intimate partner violence among pregnant women in Nigeria. Vol. 9, East Afr | Public Health. 2012. p. 29-32.

31. Hampanda KM. Intimate partner violence and HIV-positive women's non-adherence to antiretroviral medication for the purpose of prevention of mother-to-child transmission in Lusaka, Zambia. Soc Sci Med [Internet]. 2016 Mar;153:123-30. Available from: http://linkinghub.elsevier. com/retrieve/pii/S0277953616300661

32. Watts C, Seeley J. Addressing gender inequality and intimate partner violence as critical barriers to an effective HIV response in sub-Saharan Africa. J Int AIDS Soc. 2014;17(1):5-7.

33. Peltzer K, Jones D, Weiss SM, Villar-Loubet O, Shikwane E. Sexual risk serostatus and intimate partner violence among couples during pregnancy in rural South Africa. AIDS Behav [Internet]. 2013 Feb;17(2):508-16. Available from: http://www.ncbi.nlm.nih.gov/pubmed/22488126

34. Peltzer K, Mlambo G. Sexual HIV risk behaviour and associated factors among pregnant women in Mpumalanga, South Africa. BMC Pregnancy Childbirth [Internet]. 2013 Dec 4;13(1):57. Available from: BMC Pregnancy and Childbirth

35. Mayosi BM, Lawn JE, van Niekerk A, Bradshaw D, Abdool Karim SS, Coovadia HM, et al. Health in South Africa: changes and challenges since
2009. Lancet (London, England) [Internet]. 2012 Dec 8;380(9858):2029_ 43. Available from: http://dx.doi.org/10.1016/S0140-6736(12)61814-5

36. Aguilar-Zapata D, Piñeiruá-Menéndez A, Volkow-Fernández P, Rodríguez-Zulueta P, Ramos-Alamillo U, Cabrera-López T, et al. Sociodemographic differences among HIV-positive and HIV-negative recently pregnant women in Mexico City. Med (United States). 2017;96(27)

37. Narasimhan M, Orza L, Welbourn A, Bewley S, Crone T, Vazquez M. Sexual and reproductive health and human rights of women living with HIV: a global community survey. Bull World Health Organ [Internet]. 2016;94(4):243-9. Available from: http://www.who.int/entity/bulletin/ volumes/94/4/14-150912.pdf

38. Maman S, Groves AK, McNaughton Reyes HL, Moodley D. Diagnosis and disclosure of HIV status: Implications for Women's Risk of Physical Partner Violence in the Postpartum Period. JAIDS I Acquir Immune Defic Syndr [Internet]. 2016 Mar;72(5):1. Available from: http:// content.wkhealth.com/linkback/openurl?sid=WKPTLP:landingpage\& an=00126334-900000000-97264

39. Shamu S, Zarowsky C, Shefer T, Temmerman M, Abrahams N. Intimate partner violence after disclosure of HIV test results among pregnant women in Harare, Zimbabwe. PLoS One. 2014;9(10)

40. Malaju MT, Alene GD. Women's expectation of partner's violence on HIV disclosure for prevention of mother to child transmission of HIV in North West Ethiopia. BMC Res Notes [Internet]. 2013;6(1):96. Available from: BMC Research Notes

41. Flores Ceccon R, Nazareth Meneghel S. HIV e violência contra mulheres: estudo em município com alta prevalência de Aids no Sul do Brasil. Rev Panam Salud Publica [Internet]. 2015;37(4/5):287--292 6p. Available from: http://ezp-prod1.hul.harvard.edu/login?url=http://search.ebscohost. com/login.aspx?direct=true\%7B\&\%7Ddb=c8h\%7B\&\%7DAN=109821053 $\% 7 B \& \% 7 D$ site=ehost-live\%7B\&\%7Dscope=site

42. Ghosh M, Rodriguez-Garcia M, Wira CR. Immunobiology of Genital Tract Trauma: Endocrine Regulation of HIV Acquisition in Women Following Sexual Assault or Genital Tract Mutilation. Am | Reprod Immunol [Internet]. 2013 Feb;69(SUPPL.1):51-60. Available from: http://onlinelibrary. wiley.com/doi/10.1111/aji.12027/full

43. Teixeira LB, Pilecco FB, Vigo Á, Drachler M de L, Leite JC de C, Knauth $D R$. Factors associated with post-diagnosis pregnancies in women living with HIV in the south of Brazil. PLoS One [Internet]. 2017;12(2):e0172514. Available from: http://dx.plos.org/10.1371/journal.pone.0172514

44. Shahrook S, Mori R, Ochirbat T, Gomi H. Strategies of testing for syphilis during pregnancy. Cochrane database Syst Rev [Internet]. 2014 Oct 29;10(10):CD010385. Available from: http://www.ncbi.nlm.nih.gov/ pubmed/25352226

45. Cybulska B. Immediate medical care after sexual assault. Best Pract Res Clin Obstet Gynaecol [Internet]. 2013 Feb;27(1):141-9. Available from: http://dx.doi.org/10.1016/j.bpobgyn.2012.08.013

46. Ashaba S, Kaida A, Coleman IN, Burns BF, Dunkley E, O'Neil K, et al. Psychosocial challenges facing women living with HIV during the perinatal period in rural Uganda. Mazza M, editor. PLoS One [Internet]. 2017 May 1;12(5):e0176256. Available from: http://dx.plos.org/10.1371/journal. pone.0176256

47. Secor-Turner M, McMorris B, Sieving R, Bearinger LH. Life experiences of instability and sexual risk behaviors among high-risk adolescent females. Perspect Sex Reprod Health [Internet]. 2013;45(2):101-7. Available from: http://www.ncbi.nlm.nih.gov/pubmed/23750624 